\title{
직렬형 $\mathrm{HEV}$ 운전 특성 분석을 위한 PSIM 시뮬레이터
}

林德英”, 林栽寬 ${ }^{\star}$, 崔載吴†, 鄭敎範 ${ }^{*}$

\section{PSIM Simulator for Analysis of Series HEV Operation}

Deokyoung Lim, Jaekwan Im, Jaeho Choi, and Gyo-Bum Chung

$$
\text { 요 약 }
$$

본 논문에서는 직렬형 하이브리드 자동차의 운전특성을 분석하기 위한 PSIM 시뮬레이터의 개발에 대하여 기술 한다. 직렬형 하이브리드 자동차는 엔진이 전동기와 전기적으로 결합되어 있으며 전동기의 출력에 의해서만 구동된 다. 엔진/발전기, 전동기, 기어와 같은 파워트레인 각 구성요소들의 정격은 에너지 개념을 이용한 시스템과 Electrical Peaking Hybrid (ELPH)를 이용하여 모델링할 수 있는데, 설계된 하이브리드 자동차를 개발된 PSIM 시 뮬레이터를 이용하여 특정 운전주기 하에서 평가하고 분석하였다. 기계적 제동이 사용되는 경우와 회생제동이 사용 되는 경우 각각에 대하여 전동기의 평균 입력을 비교하였으며 시뮬레이션 결과를 바탕으로 직렬형 하이브리드 자 동차의 연비를 분석하였다.

\section{ABSTRACT}

This paper describes the PSIM simulator for the analysis of the series type HEV operation. The traction force of the series type HEV of which engine is electrically coupled with a traction motor is supplied from the traction motor only. The rating of each power train components, such as gear, motor, ESS, ICE/generator, is designed with the Energy-Based Modeling method and the Electrical Peaking Hybrid(ELPH) method. Under driving cycle, the designed series HEV is evaluated with the developed PSIM simulator. A comparison between the conventional braking and the regenerative braking is performed with the average motor input power. And the fuel economy analysis is carried out on the basis of the simulation results.

Key Words : Hybrid Electrical Vehicle (HEV), HEV simulator

\section{1. 서 론}

화석 연료 소모와 배기가스 배출 등의 이유로 에너 지 위기와 지구 온난화의 주된 요인으로 지목 받고 있 는 자동차 산업계는 기존의 자동차와 대비하여 연비가 개선되고 $\mathrm{CO}_{2}$ 배출량이 감소된 차량을 개발하여 출시

\footnotetext{
†교신저자 : 정회원, 충북대 전자정보대학 교수

E-mail : choi@cbnu.ac.kr

*학생회원, 충북대 전기공학과 석사과정

*정회원, 홍익대 전자전기공학과 교수

접수일자 : 2010. 10. 21

심사완료 : 2010. 11.5
}

하고 있다. Green Car 혹은 친환경 자동차라 불리는 이러한 자동차들은 기존 자동차가 화석연료를 사용하 는 내연기관에 의해서만 구동 에너지를 얻었던 것에서 벗어나 배터리/슈퍼 캐패시터, 연료전지, $\mathrm{Bio}^{-}$연료 및 기타 신재생에너지 등 그 구동 에너지원을 다양화하고 있다. ${ }^{[1]}$

하이브리드 전기자동차는 두 종류 이상의 동력원을 함께 이용하는 자동차로 보통 내연기관과 전동기의 구 동력을 차량 구동력으로 혼합하여 사용하는 개념이다. 비록 최근에 와서 하이브리드 전기 자동차가 화두가 되고 있지만 그 개념이 도입된 시기는 자동차 역사만 큼이나 오래 되었다고 할 수 있다. 1899년 Paris Salon 


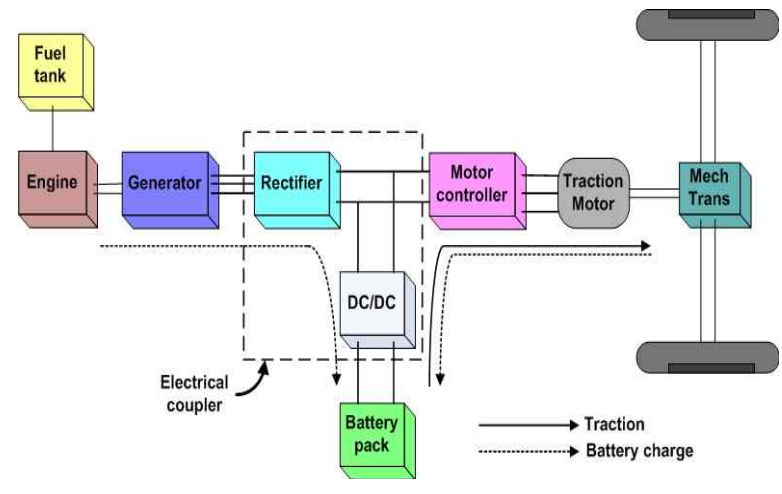

그림 1 직렬형 하이브리드 전기 자동차의 구조

Fig. 1 Configuration of a series hybrid electric drive train

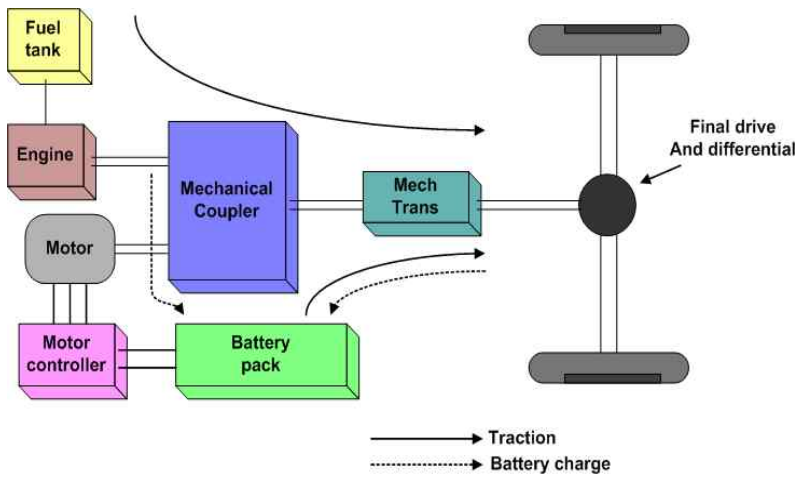

그림 2 병렬형 하이브리드 전기 자동차의 구조

Fig. 2 Configuration of a parallel hybrid electric drive train

에서 벨기에 Pieper Establishments of Liege와 프랑스 Vedovelli and Priestly Electic Carriage Company에 의해서 내연기관과 전기 모터를 사용한 직렬형과 병렬 형 하이브리드 전기 자동차가 처음 소개된 것을 시작 으로 현재는 도요타와 혼다를 선두로 포드, $\mathrm{GM}$, $\mathrm{BMW}$, 현대자동차 등 전반적인 자동차 산업계에서 그 경쟁이 심화되고 있다. ${ }^{[2]}$

하이브리드 전기 자동차는 내연기관과 전동기의 전기적, 기계적 결합 방식에 따라서 직렬형, 병렬형, 직병렬 혼 합형 등 여러 가지로 분류될 수 있다. 직렬형은 그림 1 에서와 같이 휠 구동축이 전동기에만 기계적으로 연 결되어 있으며 엔진 출력은 발전기를 통하여 ESS(Energy Storage System) 혹은 구동 전동기로 전 달되는 구조로 되어 있다. 직렬형 구조는 엔진이 최대 효율점 부근에서 운전될 수 있기 때문에 연비 측면에 서 우수한 특성을 가진다는 장점이 있다. 하지만 자동 차의 구동력이 전동기에 의해서만 공급되기 때문에 전
동기나 $\mathrm{ESS}$ 크기가 병렬형에 비해 커지게 된다. 병렬 형은 그림 2와 같이 휠 구동축이 기계적 커플러를 통 하여 전동기와 엔진에 같이 연결되어 있는 구조이다. 병렬형은 자동차의 구동력이 전동기와 엔진 두 군데에 서 공급받을 수 있으므로 전동기나 $\mathrm{ESS}$ 의 크기를 줄 일 수 있지만 엔진의 최대 효율점 운전이 어렵기 때문 에 연비는 크게 향상시킬 수 없다. ${ }^{[2],[3],[4]}$ 본 논문에서 는 직렬형 하이브리드 전기 자동차 구조를 기반으로 자동차 요구 성능에 따른 각 구성요소별 파워 정격을 설계하였다.

하이브리드 전기 자동차와 관련된 기술 개발을 위한 연구를 수행하려면 자동차 구성요소들의 상호 작용을 분석하기 위한 시뮬레이션 툴(Tool)을 필요로 한다. $\mathrm{HEV}$ 시뮬레이션과 관련된 초기 모델로는 NREL에서 개발된 $\mathrm{ADVISOR}$ 와 $\mathrm{ANRL}$ 의 $\mathrm{PSAT}$ 이 있다. $\mathrm{ADVISOR}$ 는 운전특성이나 연료변환의 효율을 분석하 기 위하여 서브시스템의 정적 맵을 사용하였는데 장시 간에 걸친 시뮬레이션을 통하여 각 구성 요소들의 운 전 전략과 구조를 설계하는데 적합하였다. ${ }^{[5]}$ 반면에 일 리노이 대학교에서 개발한 시뮬링크를 사용한 동적 모 델은 자동차 구성요소들의 손실과 동작 특성을 분석하 여 반도체 스위칭 소자의 정격 등을 평가하는데 적합 하다고 할 수 있다. ${ }^{[3],[4]}$ 하이브리드 전기 자동차의 시 뮬레이션은 보통 수백에서 수천 초의 단위로 어떠한 운행 패턴 하에서의 특성을 분석하는데 사용되기 때문 에 인버터나 컨버터의 자세한 동적 모델이나 비선형 전동기나 엔진의 제어 알고리즘 혹은 다른 서브시스템 의 동적 제어구조를 자세히 다룰 수는 없다. 본 논문 에서는 이러한 동적 제어구조들을 에너지 개념을 이용 한 시뮬레이션 모델을 기반으로 간략화하여 각 구성 요소 간 전력 흐름과 에너지의 변화를 관측할 수 있는 시뮬레이를 구성하였다.

\section{2. 구성요소 설계 ${ }^{[2],[4],[6],[7]}$}

\section{1 자동차 동적 모델링}

자동차 동적 모델링은 운전에 반(反)하거나 순(順) 하는 모든 힘으로 구성이 되며 최종적인 추진력은 (1) 과 같다.

$$
f_{\text {traction }}=\frac{1}{2} C_{D} \rho_{a} A_{f} v^{2}+M g f_{r}+M \delta a+M g \sin \theta
$$

(1)의 우변의 첫 번째 및 두 번째 항은 각각 공기 저항력과 회전마찰력을 나타내며 언제나 운전방향에 
반하게 된다. 그리고 세 번째 및 네 번째 항은 각각 가속력과 중력에 관련된 부분이며 운행 상황에 따라 자동차 운전방향에 순하게 될 수 있으므로 운동에너지 를 전동기를 통해 회생하여 사용할 수 있음을 나타낸 다.

\subsection{1 공기저항력(Air drag force)}

공기저항력은 공기에 의한 저항 성분이라 할 수 있 으며 자동차가 유체를 통과하면서 영향을 받는 두 가 지 요소에 의해 만들어 진다. 즉, 자동차의 전체적인 앞면에 가해지는 공기압과 공기가 자동차를 지나면서 생기는 마찰에 의해 만들어 진다. 이중 자동차의 일반 적인 구조에 기인하여 공기압에 의한 힘이 마찰력에 의한 힘보다 월등히 크게 된다. 공기압에 의한 공기저 항계수는 (2)로 정의된다.

$$
C_{D}=\frac{f_{d r a g}}{\frac{1}{2} \rho_{a} A_{f} v^{2}}
$$

여기서 $f_{d r a g}$ 는 자동차의 공기저항력이며, $\rho_{a}$ 는 공기 밀도, $A_{f}$ 는 자동차의 전방 면적, $v$ 는 공기가 정지하고 있다는 가정하에서 자동차 속도가 된다. 만약 공기가 정지하고 있지 않다면, 공기의 속도가 자동차의 운행 방향을 고려해 더해지게 된다. (2)를 정리하면 다음과 같이 공기저항력이 정의된다.

$$
f_{\text {drag }}=\frac{1}{2} C_{D} \rho_{a} A_{f} v^{2}
$$

여기서 공기저항계수는 대부분 실험적으로 구해지게 된다.

\subsection{2 회전마찰력(Rolling resistance force)}

회전마찰력은 자동차의 무게와 타이어의 회전에 의 해 생겨나게 된다. 타이어가 도로 위를 회전함에 따라 서 타이어는 자동차 무게에 의해 끊임없이 모양이 변 형되며 이러한 변형이 자동차 운전에 반하는 힘을 생 성하게 된다. 타이어 압이 일정하다고 가정하면 회전 마찰력은 (4)와 같이 표현된다.

$$
f_{\text {tire }}=M g f_{r}
$$

여기서 $f_{r}$ 은 회전마찰계수로 실험적으로 결정되는 상수이며, $\mathrm{M}$ 은 자동차 질량, $g$ 는 중력가속도이다.

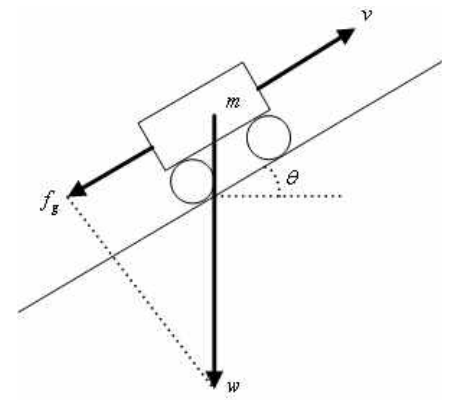

그림 3 경사면 위의 자동차

Fig. 3 Vehicle on a grade

\subsection{3 가속력(Acceleration force)}

가속력은 자동차의 질량을 가속하기 위해 필요한 힘 이다. 일반적으로 가속력은 질량 $M$ 과 가속도 $a$ 의 곱 으로 주어져야 되지만 자동차는 바퀴의 회전에 의해 가속하므로 최종 가속력은 회전 관성 요소 $\delta$ 를 고려하 여 $M \delta a$ 와 같이 표현된다.

\subsection{4 중력(Gravitational force)}

중력은 자동차가 경사면에 들어섰을 때 경사각에 의 해서 생겨나는 힘이 된다. 그림 3 은 $M$ 의 질량을 가지 고 있는 자동차가 경사각 $\theta$ 의 경사면을 운행할 때의 상태를 보여준다. 오르막의 경우 자동차 운행 방향과 반대로 힘 $f_{g}$ 가 작용하지만 내리막인 경우는 같은 방 향으로 작용한다. 자동차의 속력은 $v$, 중력 방향의 부 하는 $w$, 경사각은 $\theta$ 로 주어지면, $f_{g}$ 는 자동차 질량에 의해 생성된 총 하향 힘과 $f_{g}$ 방향의 단위벡터와의 내 적으로 (5)와 같이 표현된다.

$$
f_{g}=w \cdot \hat{i_{g}}=M g \sin \theta
$$

$$
\text { 여기서 자동차 무게는 } M g \text { 이다. }
$$

\subsection{5 자동차 추진력}

자동차 추진력은 위에 설명된 모든 힘의 합에 의해 서 (1)과같이 구해지며 $\delta$ 는 회전 관성요소를 나타낸다. 자동차의 추진파워는 (6)을 통해 쉽게 구할 수 있으며 (1)과 (6)을 이용해 자동차 운행에 필요한 추진력을 (7)과 같이 표현할 수 있다.

$$
\begin{aligned}
P_{\text {traction }} & =\frac{d E}{d t}=f_{\text {traction }} \frac{d x}{d t}=f_{\text {traction }} v \\
P_{\text {traction }} & =\frac{1}{2} C_{D} \rho_{a} A_{f} v^{3}+M g f_{r} v+M \delta a v+M g v \sin \theta
\end{aligned}
$$




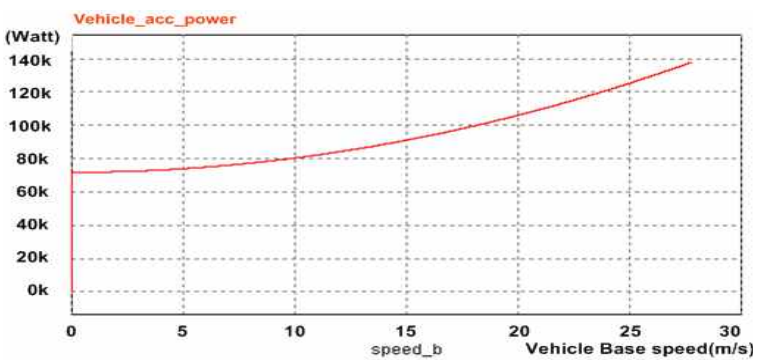

그림 4 자동차 가속에 필요한 파워 vs. 전동기 기저속도 에 해당하는 자동차 속도

Fig. 4 Vehicle acceleration power vs. Vehicle base speed

\section{2 전동기 정격설계}

직렬형 하이브리드 자동차의 전동기 정격은 자동차 가속능력과 전동기 특징과 트랜스미션의 특징에 의해 서 결정된다. 전동기 정격은 가속능력(정지상태에서 특 정 속도까지 가속시 걸리는 시간)에 의하여 (8)과 같 이 설계될 수 있다.

$$
P_{t}=\frac{\delta M}{2 t_{a}}\left(v_{f}^{2}+v_{b}^{2}\right)+\frac{2}{3} M g f_{r} v_{f}+\frac{1}{5} \rho_{a} C_{D} A_{f} v_{f}^{3}
$$

여기서 $M$ 은 자동차의 총 질량 $(\mathrm{kg}), t_{a}$ 는 가속시간 $(s), v_{b}$ 는 전동기 기저속도에 해당하는 자동차 속도 $(\mathrm{m} / \mathrm{s}), \quad v_{f}$ 는 총 가속시간 동안 도달한 최종 속도 $(\mathrm{m} / \mathrm{s}), g$ 는 중력가속도 $9.8 \mathrm{~m} / \mathrm{s}^{2}, f_{r}$ 은 회전마찰계수, $\rho_{a}$ 는 공기밀도 $\left(1.202 \mathrm{~kg} / \mathrm{m}^{3}\right), A_{f}$ 는 자동차 전방 면적 $\left(m^{2}\right), C_{D}$ 는 공기저항계수이다. (8)의 우변 첫 번째 항 은 자동차 질량을 가속시키는데 사용되는 파워를 나타 내고 두 번째 항과 세 번째 항은 회전마찰력과 공기저 항력을 극복하기 위한 평균 파워를 나타낸다. 그림 4 는 전동기의 속도비(최대속도/기저속도)가 전동기의 정격설계에 미치는 영향을 보여준다. 전동기의 최대속 도(6000rpm)에 해당하는 자동차 속도가 $41.67 \mathrm{~m} / \mathrm{s}$ 이고 전동기의 기저속도에 해당하는 자동차 속도가 그림 4 의 횡축과 같이 변할 때 전동기의 속도비가 커질수록 전동기의 정격은 줄어든다. 하지만 속도비가 커질수록 전동기의 토크가 함께 줄어들게 되므로 전동기의 속도 비는 보통 4 6의 값으로 설정한다.

\section{3 엔진/발전기 정격설계}

직렬형 하이브리드 자동차에서 엔진/발전기는 배터 리가 완전 방전되는 것을 막기 위해 안정된 파워를 공 급하는데 그 목적이 있다. 엔진/발전기의 정격설계에서
고려되어야할 사항은 두 가지가 있다. 첫째는 고속도 로 운행 같은 장시간에 걸친 고속의 정속도 운전, 둘 째는 도시 운행 패턴과 같이 빈번한 정지 - 출발이 존 재하는 경우이다. 첫 번째 운행 패턴의 경우는 고속의 자동차의 운전을 위한 전원공급이 전적으로 $\mathrm{ESS}$ 에만 의존하지 않으며 엔진/발전기가 충분한 파워를 공급할 수 있어야 한다. 두 번째 운행 패턴의 경우는 엔진/제 너레이터가 자동차의 빈번한 가속이나 오르막의 운행 을 위하여 $\mathrm{ESS}$ 에 저장된 에너지를 특정 수준으로 유 지시킬 수 있는 파워를 공급해야 한다. 그렇기 때문에 엔진/발전기 시스템 디자인에 있어서 파워능력은 고속 도로 정속도 운행을 위한 파워보다 커야하고 도시패턴 의 운행을 위한 평균파워보다 커야한다. 고속도로 운 행 패턴과 같은 평탄한 길의 정속도 운행에서 구동전 원(엔진/발전기 혹은 $\mathrm{ESS}$ )의 출력은 (9)로 표현된다.

$$
P_{e / g}=\frac{v}{1000 \eta_{t} \eta_{m}}\left(M_{g} f_{r}+\frac{1}{2} \rho_{a} C_{D} A_{f} v^{2}\right)
$$

여기서 $\eta_{t}$ 와 $\eta_{m}$ 은 트랜스미션과 전동기의 효율을 나타낸다.

자동차가 도시형 패턴으로 운행될 때 엔진/발전기가 공급하는 파워는 $\mathrm{ESS}$ 의 에너지를 안정하게 유지하기 위 하여 (10)처럼 평균 부하파워와 같거나 조금 커야한다.

$$
P_{\text {ave }}=\frac{1}{T} \int_{0}^{T}\left(M g f_{r}+\frac{1}{2} \rho_{a} C_{D} A_{f} v^{2}\right) v d t+\frac{1}{T} \int_{0}^{T} \delta M \frac{d v}{d t} d t
$$

(10)에서 우변 첫 번째 항은 자동차 회전마찰과 공 기저항을 극복하기 위한 평균 파워를 나타내고 두 번 째 항은 자동차 가속과 감속을 위한 평균 파워를 나타 낸다. 엔진/발전기 설계시 (9)와 (10)을 비교하여 큰 파워를 기준으로 정격을 정하게 되는데 보통 (9)가 (10)보다 큰 값을 가진다. 이와 함께 엔진의 효율맵도 함께 고려하여 엔진/발전기 설계를 해야 한다.

\subsection{ESS 설계}

\subsubsection{ESS 파워 용량}

전동기의 정격운전을 위해서 엔진/발전기와 $\mathrm{ESS}$ 의 총 파워는 전동기의 정격파워보다 커야한다. 그러므로 $\mathrm{ESS}$ 의 파워 용량은 (11)과 같이 표현된다.

$$
P_{E S S} \geq \frac{P_{m, \max }}{\eta_{m}}-P_{e / g}
$$


여기서 $P_{m, \max }$ 는 전동기 최대정격, $\eta_{m}$ 은 모터효율, $P_{e / g}$ 는 엔진/전동기 시스템의 파워를 나타낸다.

\subsubsection{ESS 에너지 용량}

$\mathrm{ESS}$ 의 에너지 변화는 (12)와 같이 표현된다.

$$
\triangle E=\int_{0}^{T} P_{E S S} d t
$$

여기서 $P_{E S S}$ 는 $\mathrm{ESS}$ 의 파워이며 양의 값은 충전 음 의 값은 방전을 나타낸다. $\mathrm{ESS}$ 의 에너지 변화는 그 제어 방법과 밀접한 연관이 있다. 만약 $\mathrm{ESS}$ 의 $\mathrm{SOC}$ 운전영역이 $S O C_{h i g h}$ 와 $S O C_{l o w}$ 사이고 그때의 에너지 변화 허용량이 $\triangle E$ 일 때 $\mathrm{ESS}$ 의 총 에너지 용량은 (13)으로 설계된다.

$$
E_{E S S}=\frac{\triangle E_{\max }}{S O C_{\text {high }}-S O C_{\text {low }}}
$$

\section{5 제동 시스템 설계}

하이브리드 자동차의 장점중 하나는 제동에너지의 일부를 회생하여 사용할 수 있다는 것이다. 회생제동 시 전동기는 발전기로 동작하여 자동차의 운동에너지 혹은 위치에너지를 $\mathrm{ESS}$ 에 저장하여 사용할 수 있는 전기에너지로 바꿔준다. 하지만 일반적으로 강한제동 에 필요한 토크는 전동기가 만들어낼 수 있는 토크보 다 크기 때문에 하이브리드 자동차는 기계적인 제동을 회생제동과 함께 사용한다.

자동차 진행 방향으로 안전한 제동을 위해서는 전륜 과 후륜에 적절한 제동력 분배가 되어야 한다. 제동력 은 (14)와 같고 제동토크가 증가함에 따라 함께 증가 하지만 타이어와 노면의 점착력에 의해 그 크기는 (15)와 같이 제한된다.

$$
\begin{aligned}
& F_{b}=\frac{T_{b}}{r_{d}} \\
& F_{b \max }=\mu W
\end{aligned}
$$

여기서 $r_{d}$ 는 타이어 반지름 $\mu$ 는 타이어-노면의 점 착계수 $W$ 는 수직하중을 나타낸다. 점착계수 $\mu$ 는 자동 차 휠과 타이어의 슬립과 노면상태에 의해서 변하게 되며 노면 상태에 따른 점착계수의 변화는 표 1 과 같 다.

그림 5 와 같이 제동이 걸릴 때 제동력은 전륜과 후 륜에 분배 된 수직하중에 비례한다. 제동시 $\mathrm{A}$ 점과 $\mathrm{B}$

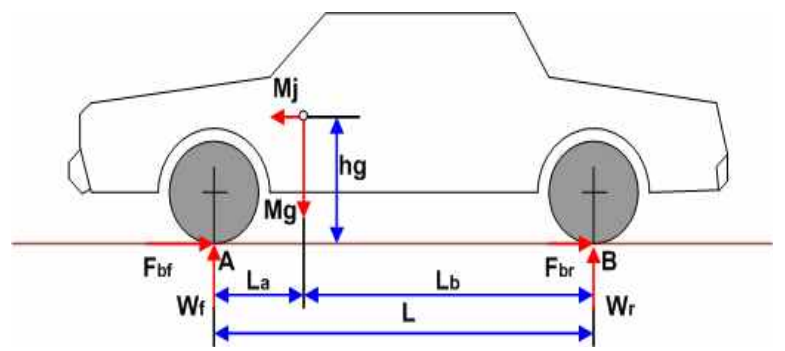

그림 5 제동시 발생하는 힘

Fig. 5 Force during braking

표 1 타이어-노면 평균 점착계수

Table 1 Average Tire-road adhesive coefficient

\begin{tabular}{|c|l|l|}
\hline Surface & Peaking Values & Slipping Values \\
\hline Asphalt and concrete(dry) & $0.8-0.9$ & 0.75 \\
\hline Concrete(wet) & 0.8 & 0.7 \\
\hline Asphalt(wet) & $0.5-0.7$ & $0.45-0.6$ \\
\hline Gravel & 0.6 & 0.55 \\
\hline Earth road(dry) & 0.68 & 0.65 \\
\hline Earth road(wet) & 0.55 & $0.4-0.5$ \\
\hline Snow & 0.2 & 0.15 \\
\hline Ice & 0.1 & 0.07 \\
\hline
\end{tabular}

점 사이에 수직하중의 이동이 없다고 가정하였을 때 감속비 $j$ 와 전륜 - 후륜에 분배되는 하중 $W_{f}$ 와 $W_{r}$ 은

(16), (17), (18)과 같이 표현할 수 있다. 전륜과 후륜 에 걸리는 제동력과 $W_{f}$ 와 $W_{r}$ 의 비례관계를 이용하면 (19)를 구할 수 있고 (15)와 (19)에 의해서 이상적 제 동력 분배가 이루어진다.

$$
\begin{aligned}
& j=\frac{F_{b f}+F_{b r}}{M} \\
& W_{f}=\frac{M g}{L}\left(L_{b}+h_{g} \frac{j}{g}\right) \\
& W_{r}=\frac{M g}{L}\left(L_{a}-h_{g} \frac{j}{g}\right) \\
& \frac{F_{b f}}{F_{b r}}=\frac{W_{f}}{W_{r}}=\frac{L_{b}+h_{g} j / g}{L_{a}-h_{g} j / g}
\end{aligned}
$$

자동차의 각 휠이 완벽히 제어되고 타이어와 노면의 점착계수가 0.9 로 일정하다는 가정아래 구동륜(보통 전 륜)으로 분배된 모든 제동력이 회생가능하다면 구동축으 로의 제동력분배가 최대가 되도록 제동시스템을 설계하 여야 하며 이는 그림 6의 ECE-regulation 커브를 따라 서 제동력을 분배하는 것이라 할 수 있다 (ECE-regulation 커브는 안전한 제동을 위해 피동륜으로 


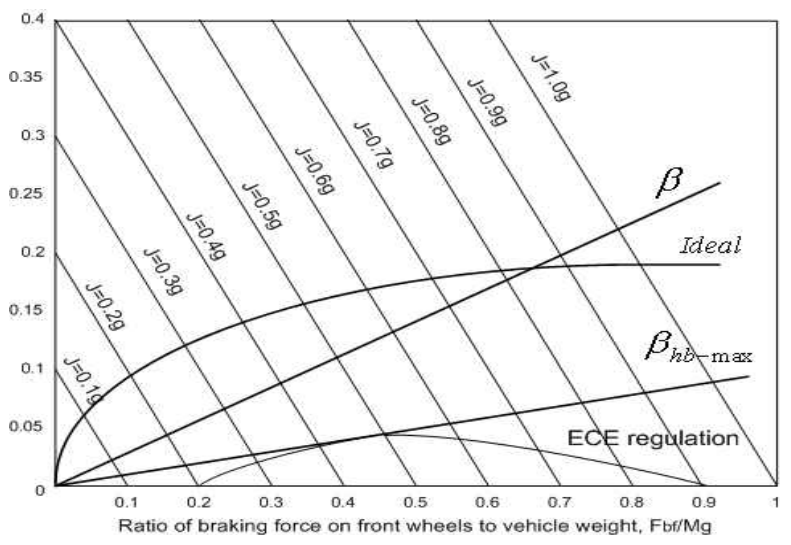

그림 6 제동력 분배 커브

Fig. 6 Braking force distribution curve

분배되어야하는 최소한의 제동력 분배비를 나타낸다). 하지만 회생제동의 크기가 전동기의 정격이나 $\mathrm{ESS}$ 의 정격에 의해서 제한되므로 ECE-regulation 커브에 의 해서 구동륜으로 분배된 제동력이 회생 가능한 최대의 제동력을 넘어서면 제동력 분배가 이상적 분배비인 Ideal커브를 따라가도록 설계한다. 그림 6에서 알 수 있듯이 ECE-regulation 커브는 비선형 곡선으로 나타 나므로 용이한 제동시스템의 설계를 위해 이를 대체할 수 있는 선형화된 (20)의 $\beta_{h b-\max }$ 를 설계하여 ECE-regulation 커브를 대체하여 사용한다. (21)은 최 종적인 회생제동력을 나타낸다.

$$
\begin{aligned}
& \beta_{h b-\max }=\frac{2 \sqrt{0.07 L_{b} h_{g}}+L_{b}+0.07 h_{g}}{0.85 L} \\
& P_{b-i n}=\alpha v\left(M g f_{r}+M g \sin \theta+\frac{1}{2} \rho_{a} C_{D} A_{f} v^{2}+M \delta \frac{d v}{d t}\right)
\end{aligned}
$$

여기서 $\alpha$ 는 전체 제동력에서 회생제동 비율을 나타 낸다.

\section{3. 시뮬레이터 설계}

\section{1 전동기와 기어비}

표 2의 시뮬레이션 파라미터를 사용하여 표 3 의 자 동차능력치를 만족하기 위한 전동기 정격은 (8)에 의 하여 $80 \mathrm{~kW}$ 로 계산되며 전동기 속도비 5 를 기준으로 설계된 전동기 속도-토크, 속도-파워 특성은 그림 7 과 같다.

기어비는 전동기의 최대 속도에서 자동차가 최고 속 도에 도달하도록 (22)와 같이 설계한다.

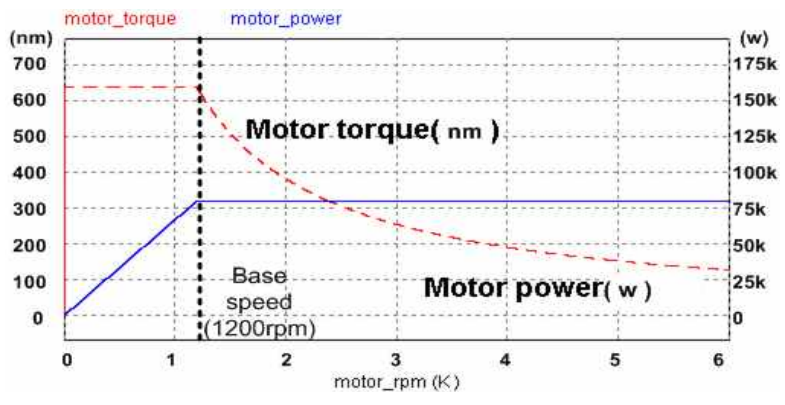

그림 7 전동기 토크-속도, 파워-속도 그래프

Fig. 7 Motor torque-speed, power-speed graph

표 2 시뮬레이션 파라미터

Table 2 Simulation parameters

\begin{tabular}{|l|c|}
\hline \multicolumn{1}{|c|}{ Parameters } & Values \\
\hline Vehicle total mass $(M)$ & $1500 \mathrm{~kg}$ \\
\hline Inertial factor $(\delta)$ & 1.14 \\
\hline Tire radius $\left(r_{d}\right)$ & $0.3 \mathrm{~m}$ \\
\hline Rolling resistance coef $\left(f_{r}\right)$ & 0.01 \\
\hline Aerodynamic drag $\operatorname{coef}\left(C_{D}\right)$ & 0.3 \\
\hline Frontal $\operatorname{area}\left(A_{f}\right)$ & $2.0 \mathrm{~m}^{2}$ \\
\hline Air density $\left(\rho_{a}\right)$ & $1.202 \mathrm{~kg} / \mathrm{m}^{3}$ \\
\hline Transmission $\operatorname{efficiency}\left(\eta_{t}\right)$ & 0.9 \\
\hline Motor efficiency $\left(\eta_{m}\right)$ & 0.85 \\
\hline
\end{tabular}

표 3 자동차 설계 스펙

Table 3 Vehicle design specification

\begin{tabular}{|l|c|}
\hline \multicolumn{1}{|c|}{ Specifications } & Values \\
\hline Motor base speed & 1200rpm \\
\hline Motor maximum speed & $6000 \mathrm{rpm}$ \\
\hline Acceleration time $(0 \sim 100 \mathrm{~km} / \mathrm{h})$ & $10 \pm 1 \mathrm{~s}$ \\
\hline Maximum speed & $150 \mathrm{~km} / \mathrm{h}$ \\
\hline Gear ratio & 4.5216 \\
\hline
\end{tabular}

$R_{g}=\frac{\pi n_{m \cdot \max } r}{30 v_{\max }}$

여기서 $n_{m \cdot \max }$ 는 전동기의 최대 $\mathrm{rpm}, v_{\max }$ 는 자동차 최고 속도 $(\mathrm{m} / \mathrm{s}), \mathrm{r}$ 은 타이어 반경을 나타낸다. 전동기 최대 $\mathrm{rpm} 6000$, 자동차 최고 속도 $44.4 \mathrm{~m} / \mathrm{s}$, 타이어 반 경 $0.3 \mathrm{~m}$ 를 기준으로 계산된 기어비는 4.5216 이 된다.

\section{2 엔진/발전기 설계}

고속도로 운행패턴을 기준으로 평탄한 길에서 자동 


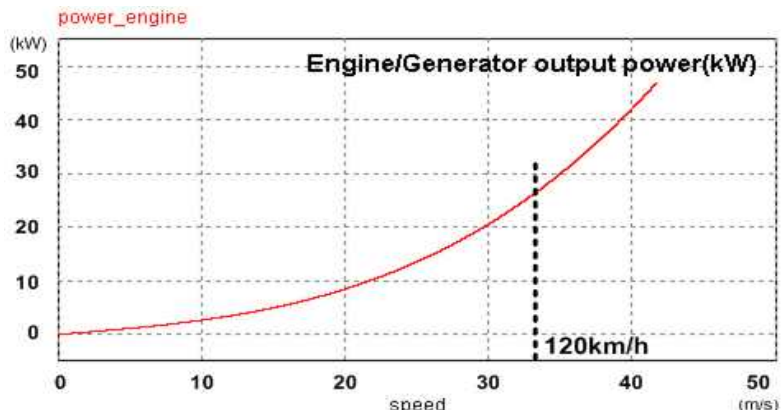

그림 8 정속주행에 필요한 엔진 출력

Fig. 8 Engine Power requirement for constant speed drive

차 속력 $120 \mathrm{~km} / \mathrm{h}$ 를 유지하기 위한 엔진/발전기 출력은 (9)에 의해 $27 \mathrm{~kW}$ 로 계산된다. 그림 8 은 각 속도의 정 속주행에 필요한 엔진 파워를 보여준다.

\subsection{ESS 설계}

엔진/발전기와 $\mathrm{ESS}$ 의 출력은 전동기 입력 파워보다 크거나 같아야 한다. 전동기 정격 $80 \mathrm{~kW}$ 에서 엔진 출 력 $27 \mathrm{~kW}$ 를 제외한 나며지를 $\mathrm{ESS}$ 에서 공급하도록 (23)에 의하여 계산하면 $67.2 \mathrm{~kW}$ 가 된다.

$$
P_{E S S}=\frac{P_{\text {motor }}}{\eta_{\text {motor }}}-P_{e / g}=\frac{80}{0.85}-27=67.2 k \mathrm{~W}
$$

$\mathrm{ESS}$ 의 에너지 용량은 자동차 운행 패턴과 제어 방 법에 크게 의존한다. $\mathrm{ESS}$ 의 최대 에너지 변화 허용량 이 $0.9 \mathrm{kWh}$ 이고 0.3 의 $\mathrm{SOC}$ 변동 범위를 가진다면 총 $\mathrm{ESS}$ 저장에너지는 (24)처럼 설계된다.

$$
E_{E S S}=\frac{\triangle E_{\max }}{\triangle S O C}=\frac{0.9}{0.3}=3 k W h
$$

\section{4 제동 시스템 설계}

$0.2 \mathrm{~g}, 0.3 \mathrm{~g}, 0.4 \mathrm{~g}$ 의 감속비에서 자동차 속도에 따른 제동력 분배를 그림 9 에 보인다(건조한 아스팔트 도로 의 타이어-노면 점착계수 $(\mu) 0.9$ 하에서 최대 감속비 는 $0.9 \mathrm{~g}$ ). 전륜에서 회생 가능한 최대 전력은 $\mathrm{ESS}$ 정 격으로 설정하였다. 저속 $(15 \mathrm{~km} / \mathrm{h}$ 이하)에서는 제동시에 발생하는 전동기의 유기기전력이 작기 때문에 회생제 동을 사용하지 않고 기계적인 제동을 사용한다. 그림 9에서 제동비가 커질수록 최대로 회생 가능한 에너지 에 도달하는 속도는 작아지며 그림 6 의 $\beta_{h b-\max }$ 에 의 한 전륜으로의 제동력 분배가 최대 회생가능 에너지에 도달한 이후(전륜의 회생에너지 포화지점)에는 전륜의

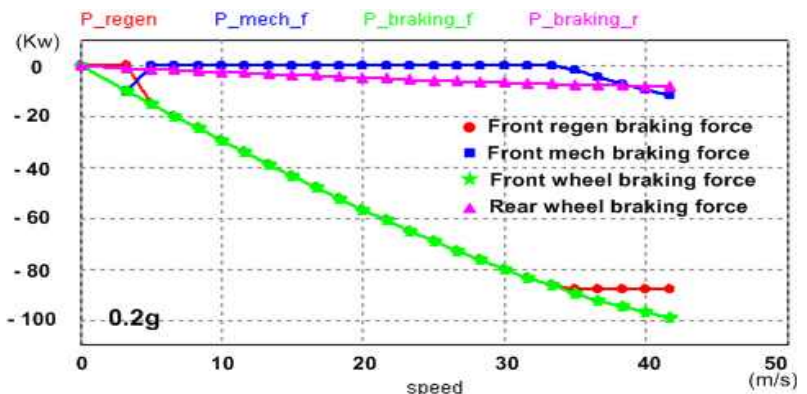

(a)

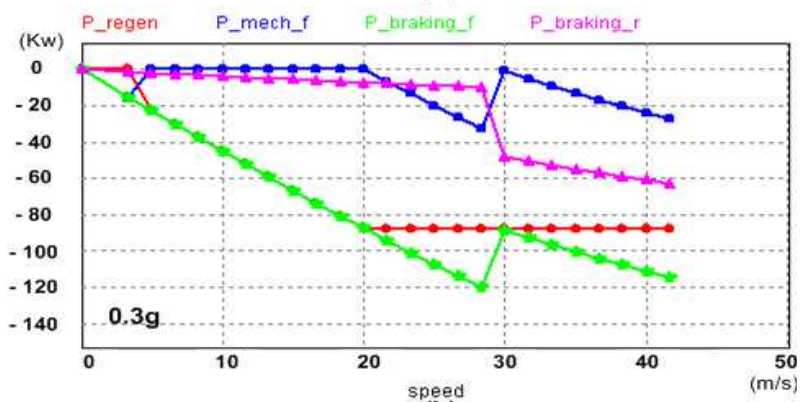

(b)

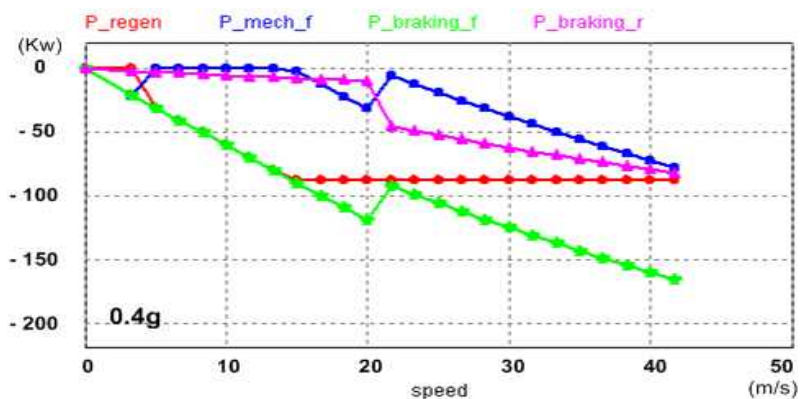

(c)

그림 9 감속비에 따른 제동력분배; (a) $0.2 \mathrm{~g}$, (b) $0.3 \mathrm{~g}$, (c) $0.4 \mathrm{~g}$

Fig. 9 Baking force distribution as deceleration rates;

(a) $0.2 \mathrm{~g}$, (b) $0.3 \mathrm{~g}$, (c) $0.4 \mathrm{~g}$

기계적 제동이 증가한다. 이후 그림 6의 Ideal커브에 의해 전륜으로 분배된 제동력이 최대 회생가능 에너지 를 초과하면 Ideal커브에 의해 전륜과 후륜의 제동력 분배가 이루어진다.

\section{4. 시뮬레이터 동작특성과 결과 - 분석}

\section{1 시뮬레이터 동작특성}

시뮬레이터는 PSIM을 사용하여 DLL파일로 구성하 였으며 시뮬레이션 흐름도는 그림 10 과 같다. 시뮬레 이션에 사용된 자동차 운행 사이클은 빈번한 가속과 감속이 존재하는 도시형 운행패턴을 가정하여 임의로 설계하였다. 자동차 운행 사이클로부터 각 시간별 자 


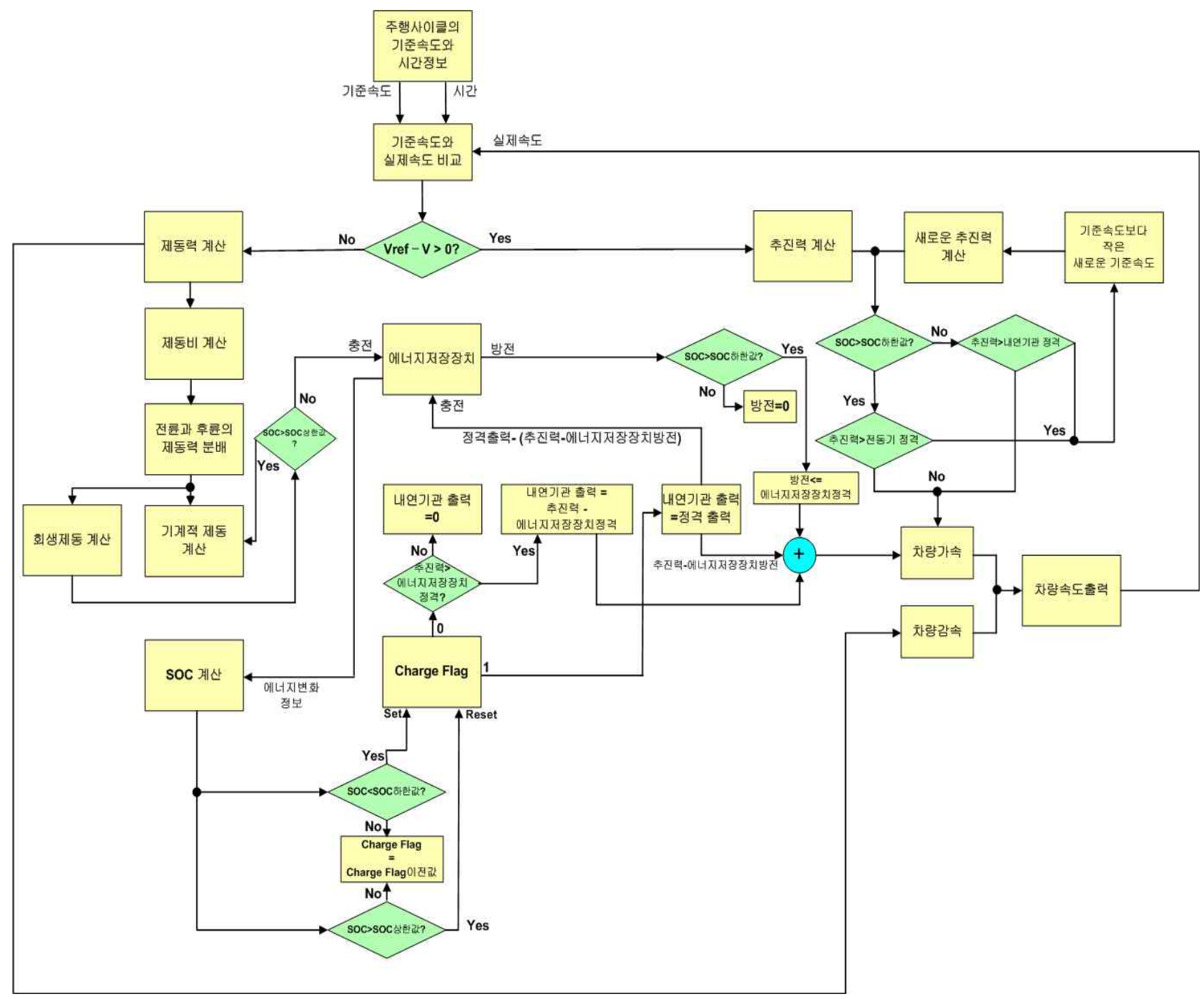

그림 10 시뮬레이션 흐름도

Fig. 10 Simulation flow chart

동차 속도 정보가 입력되면 전단계의 시뮬레이션 스텝 에서 계산되어진 자동차 속도 출력과의 비교를 통해서 가속과 감속 조건을 결정하게 된다. 자동차의 가속 조 건 하에서는 (7)을 사용하여 필요한 추진력을 계산하 지만 하이브리드 전기자동차가 만들어 낼 수 있는 추 진력은 에너지저장장치의 $\mathrm{SOC}$ 에 따라서 제한된다. 따 라서 $\mathrm{SOC}$ 값이 설정된 하한 값보다 크면 내연기관과 에너지저장장치로부터 추진력을 만들어낼 수 있지만 $\mathrm{SOC}$ 값이 설정된 하한 값보다 작으면 자동차의 추진 력은 내연기관에 의해서만 만들어지게 된다. SOC 값 에 따라서 자동차가 만들어 낼 수 있는 최대 추진력이 결정되면 주행 사이클 입력으로부터 계산되어진 추진 력과 비교를 통해서 자동차의 실제 속도를 결정한다.
계산된 추진력이 자동차가 만들어 낼 수 있는 최대추 진력을 넘지 않으면 자동차의 속도는 주행 사이클 기 준속도에 도달할 수 있지만 계산된 추진력이 자동차가 만들어 낼 수 있는 최대추진력을 넘게 되면 주행 사이 클로부터 입력된 기준속도를 조금씩 줄여가면서 최대 추진력을 넘지 않는 속도를 찾아가게 된다. 자동차의 감속조건에서는 (21)에서 $\alpha=1$ 로 설정해서 필요한 제 동력을 계산한다. 계산된 제동력은 (19)와 (20)의 두 가지 제동력 분배비에 따라서 전륜과 후륜으로 제동력 을 분배한다. 만약 (19)에 의해서 구동륜으로 분배된 제동력이 회생 가능한 최대 파워보다 크다면 제동력 분배는 (19)를 따라 이상적 분배가 되도록 하고 회생 가능한 최대 파워보다 작다면 제동력 분배는 (20)에 
따라 그 감속비에서 최대의 회생이 되도록 가능한 많 은 제동력을 구동륜으로 분배하게 된다. 전륜이 구동 륜이라는 가정 하에 전륜으로 분배된 제동력이 회생 가능한 최대 파워보다 작다면 전륜의 모든 제동력은 전동기를 통하여 에너지저장장치로 회생되며 전륜의 제동력이 회생 가능한 최대 파워보다 크다면 회생제동 제한 값 이상의 제동력은 후륜의 제동력과 함께 기계 적 제동으로 소비된다. 에너지저장장치의 SOC는 (12) 와 같이 각 스텝마다 에너지저장장치의 입·출력 파워 를 적분하여 에너지 변화를 계산하고 단계별 에너지저 장장치의 에너지 상태와 에너지 용량의 비를 통하여 구할 수 있다. 내연기관의 출력은 에너지저장장치의 $\mathrm{SOC}$ 상태와 추진력의 크기에 따라 바뀐다. 에너지저 장장치의 $\mathrm{SOC}$ 값이 설정된 하한 값에 도달하면 내연 기관은 정격출력으로 $\mathrm{SOC}$ 값이 상한 값에 도달할 때 까지 에너지저장장치를 충전한다. 또한 $\mathrm{SOC}$ 하한 값 이상의 상태에서 자동차 운행에 필요한 추진력이 에너 지저장장치의 정격보다 크게 되면 내연기관이 여분의 추진력을 공급하게 된다. 하이브리드 전기자동차의 성 능 분석을 위해서 시뮬레이션이 진행되는 동안 자동차 의 실제 속도와 시간, 내연기관의 출력상태, 회생제동 의 크기 등의 정보를 이용하여 주행거리, 연료소비, 연 비 등을 계산할 수 있다.

\section{2 시뮬레이션 결과}

그림 11 은 표 2 와 표 3 의 파라미터들을 이용한 시뮬 레이션 결과파형이다. 속도 기준값에(그림 11 (a)) 따 라서 자동차 주행에 필요한 추진력(그림 $11(\mathrm{~b})$ )이 계 산되면 전동기의 입력파워(그림 11 (c))가 계산된다. 제동시에는 $\mathrm{ESS}$ 의 정격에 따라서 회생에너지에 제한 이 걸리게 된다. 그림 11 (a)에서 설계된 $\mathrm{HEV}$ 가 속도 기준값을 잘 따라가는 것을 확인할 수 있으며 이는 자 동차 각 구성요소들의 설계가 시뮬레이션에서 사용된 주행 패턴을 만족하고 있음을 나타낸다. 그림 11 (d)에 서는 설정된 $\mathrm{ESS} \mathrm{SOC}\left(S O C_{\text {high }}=0.7, S O C_{\text {low }}=0.4\right)$ 에 따 라서 $\mathrm{ESS}$ 가 충·방전되고 있는 것을 확인할 수 있으며 $570 \sim 700 \mathrm{sec}$ 와 $1370 \sim 1500 \mathrm{sec}$ 사이에 엔진/발전기에 의 해서 $\mathrm{ESS}$ 가 충전되고 있음을 알 수 있다.

\section{3 시뮬레이션 결과분석}

그림 12 (a)는 그림 11 (a)와 같은 속도입력으로 시 뮬레이션을 수행했을 때 회생제동을 할 때와 하지 않 을 때 $0 \mathrm{~s}$ 에서 각 시간 스텝까지의 평균 전동기입력 파 워를 나타낸다. 기계적인 제동만을 사용할 때 최종 평
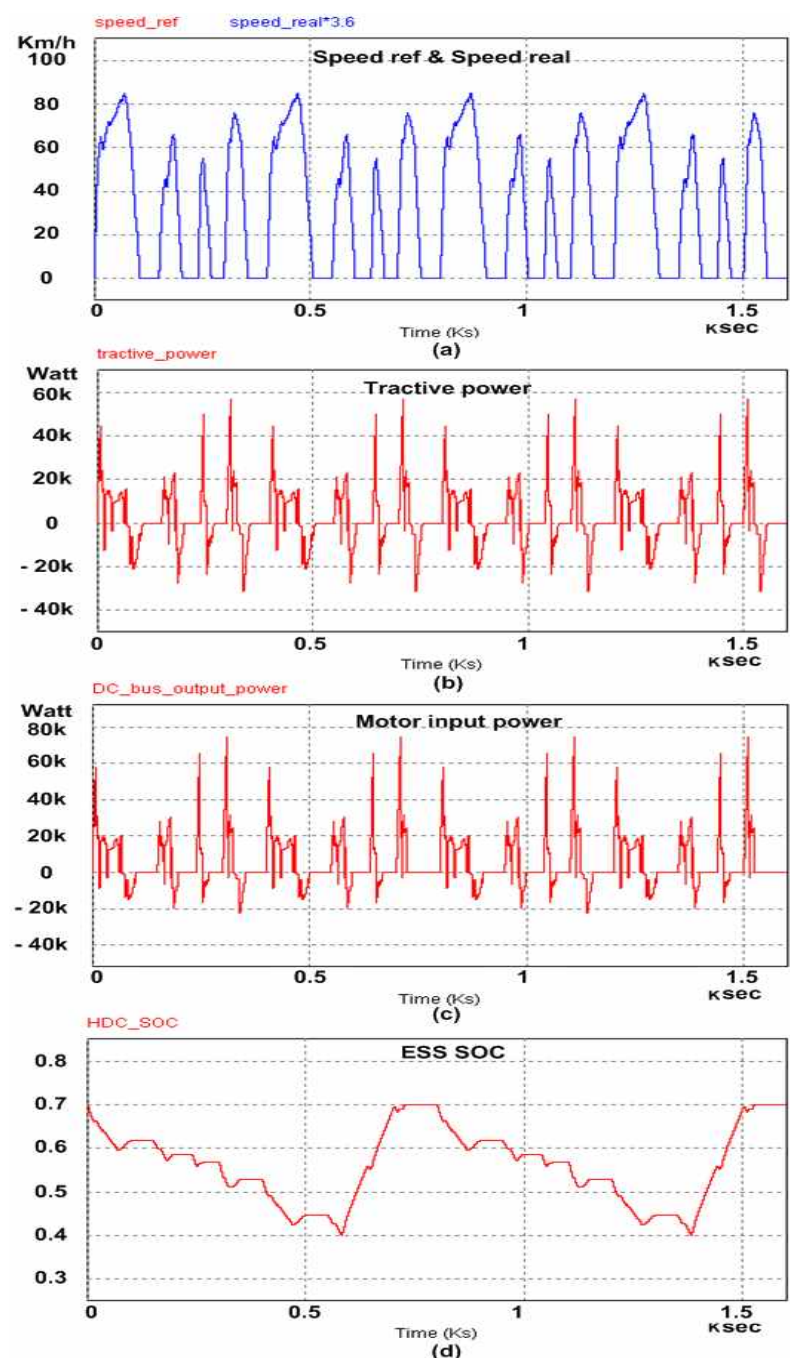

그림 11 (a) 속도레퍼런스와 속도출력, (b) 자동차 추진력, (c) 전동기 입력 파워, (d) ESS SOC

Fig. 11 (a) Speed reference and speed real, (b) tractive power, (c) motor input power, and (d) ESS SOC

균 파워는 약 $6.5 \mathrm{~kW}$ 로 회생제동을 사용할 때 평균 파 워인 $3.7 \mathrm{~kW}$ 보다 많은 전력을 소비하는 것을 확인할 수 있다. 그림 12 (b)는 자동차의 주행거리와 연료소비 를 나타낸다. 엔진이 대부분 최대 효율점(약 $34 \%$ )에서 동작하고 엔진의 연료소비율이 $250 \mathrm{~g} / \mathrm{kWh}$, 휘발유 $1 \mathrm{~L}$ 당 $740 \mathrm{~g}$ 이라 가정 했을 때 그림 11 (a)와 같은 주행패 턴으로 $13.7 \mathrm{~km}$ 이동시 약 $0.809 \mathrm{~L}$ 의 연료가 소비됨을 확인 할 수 있으며 최종 연비는 $17 \mathrm{~km} / \mathrm{L}$ 로 계산된다. 그림 12 (c)는 엔진의 출력 파워와 에너지를 나타낸다. $\mathrm{ESS}$ 의 정격을 넘어서는 파워가 요구될 경우 엔진에서 에너지를 공급하며 $\mathrm{ESS} \mathrm{SOC가} \mathrm{하한} \mathrm{값에} \mathrm{다다르면}$ 엔진이 $\mathrm{ESS}$ 를 충전하게 된다. 주행 사이클 동안 총 

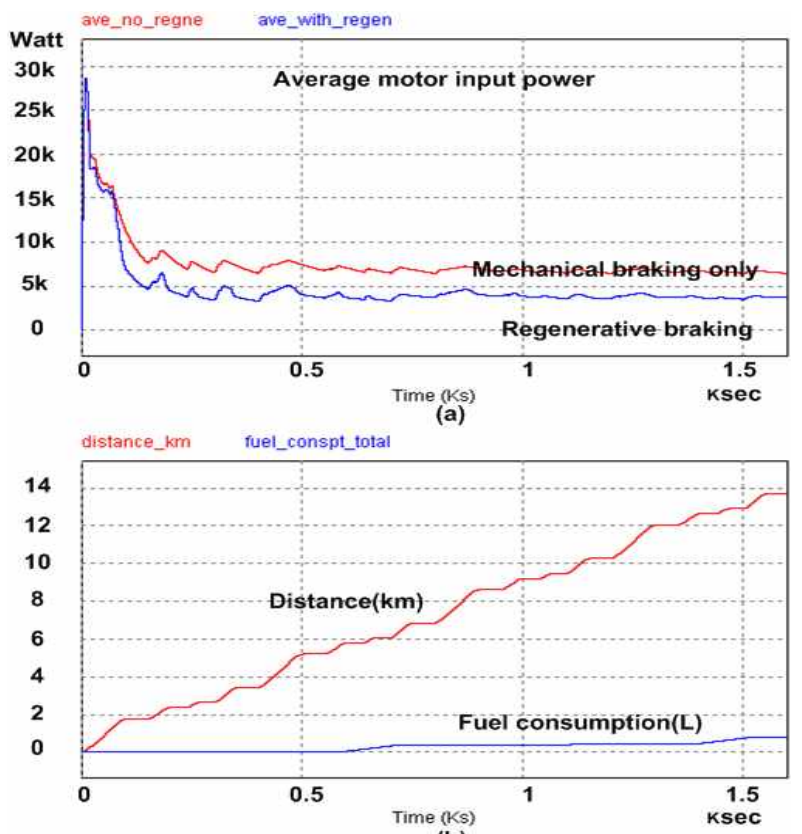

(b)

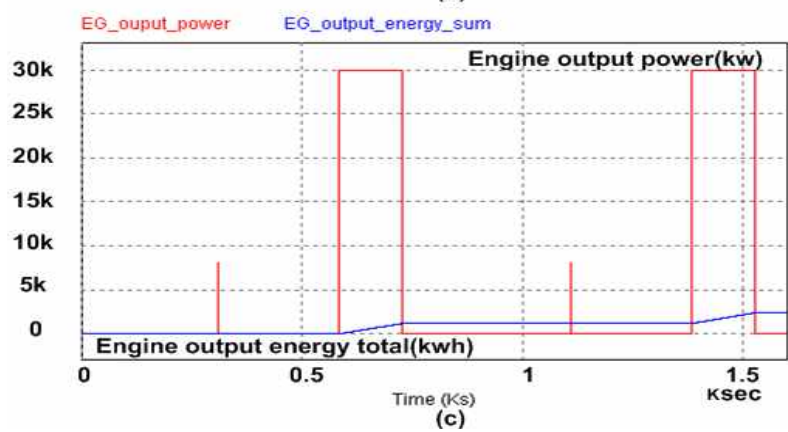

그림 12 (a) 평균 전동기 입력 파워, (b)주행거리와 연료 소비, (c) 엔진 출력 파워와 에너지

Fig. 12 (a) Average motor input power, (b) mi leage and Fuel consumption, (c) Engine output power and energy

엔진 출력 에너지는 $2.4 \mathrm{kWh}$ 가 되며 엔진의 출력 파워 에서 알 수 있듯이 자동차 속도에 독립적으로 최대 효 율점 부근에서 엔진이 운전되고 있음을 알 수 있다.

시뮬레이션 결과 직렬형 하이브리드 자동차는 도시 형 운행패턴 하에서 기존의 자동차 대비 연비가 향상 되는 것을 확인할 수 있었으며 이는 회생제동의 영향 과 엔진의 최대 효율점 운전으로 설명될 수 있다.

\section{5. 결 론}

본 논문은 하이브리드 전기 자동차의 운전 특성 분 석을 위해 에너지 개념을 이용한 PSIM 시뮬레이터를
구성하였다. 시뮬레이션 결과 직렬형 하이브리드 자동 차는 기존의 자동차 엔진이 낮은 효율점에서 운전되던 것을 최대 효율점 부근에서 운전이 가능하게 함으로써 연료소비 효율을 늘리고 제동시 마찰에 의해 소비되던 제동 에너지의 일부를 회생하여 연비를 향상시키는 것 을 알 수 있었다. 하이브리드 자동차의 최적설계는 임 의의 운행 패턴에서 자동차가 요구하는 성능을 만족하 고 각 구성요소들이 과도한 용량으로 설계되지 않도록 하는 것이며 이러한 맥락에서 하이브리드 자동차 시뮬 레이터는 하나의 평가 툴(tool)로 사용되어질 수 있다. 하이브리드 자동차의 시뮬레이터 개발은 본 논문에서 설명된 것보다 훨씬 복잡하고 추가되어야할 기술적 요 소들이 많지만, $\mathrm{HEV}$ 성능평가 및 개발과정에서 본 논 문의 시뮬레이터를 사용함으로써 하이브리드 자동차 개발 시간과 비용을 감소시킬 수 있다.

"본 연구는 지식경제부 및 정보통신산업진흥원의 대학 IT연구센터 지원사업의 연구결과로 수행되었 음" (NIPA-2009-(C1090-0904-0007))

\section{참 고 문 헌}

[1] 김경서, 이영국, 박래관, 허진, 박진호, 이백행, 이병국, 임 성민, “그린카 전기동력 시스템”, 전력전자학회 기술보고 서, pp. 1-26, 2010. 7.

[2] Mehrdad Ehsani, Yimin Gao,and Ali Emadi, Modern Electric, Hybrid Electric, and Fuel Cell Vehicles 2nd Edition, pp. 253-279, CRC Press, 2010.

[3] P.T. Krein, S. Splater, C. Hidrovo, and D. Logue, "Hybrid vehicle testing and simulation final report", Univ. Illinois, Tech Rep. PAP-TR-97-6, 1997, July.

[4] D. L. Logue and P.T. Krein, "Dynamic hybrid electric vechicle simulation, Version 1.0", Univ. Illinois, Tech Rep. UILU-ENG-98-0409, 1998, Dec.

[5] K. B. Wipke, M. R. Cuddy, and S. D. Burch, "ADVISOR 2.1: A user-friendly advanced powertrain simulation using a combined backward/forward approach", IEEE Trans. Veh Tech., Vol. 48, No. 6, pp. 1751-1761, 1999, Nov.

[6] Mehrdad Ehsani, Yimin Gao, and Karen L. Butler, "Application of Electrically Peaking Hybrid(ELPH) Propulsion System to a Full-size Passenger Car with Simulated Design Verification," IEEE Trans, Veh Tech, Vol. 48, No. 6, pp. 1779-1787, 1999. 
[7] Mehrdad Ehsani, Khwaja M. Rahman, and Hamid A. Toliyat, "Propulsion System Design of Electric and Hybrid Vehicles", IEEE Trans. Ind. Electronics, Vol. 44, No. 1, pp. 19-27, 1997.

$$
\text { 저 자 소 개 }
$$

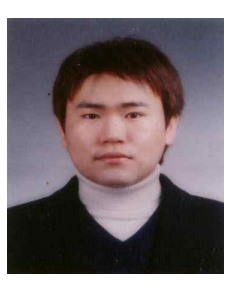

임덕 영 (林德英)

1982년 1월 1일생. 2008년 충북대 전기 전자 컴퓨터공학부 졸업. 2008년 2009년 AMK FEP부 사원. 2010년 현재 동 대학원 전기공학과 석사과정.

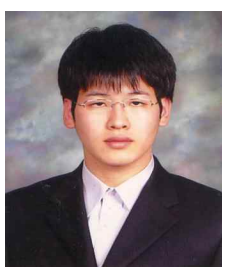

임재 관(林栽寬)

1985년 12월 11일생. 2009년 충북대 전기 전자컴퓨터공학부 졸업. 2010년 현재 동 대학원 전기공학과 석사과정.

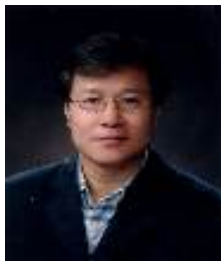

\section{최재호(崔載昊)}

1955년 9월 27일생. 1979년 서울대 공대 전기공학과 졸업. 1981년 동 대학원 전기공학과 졸업(석사). 1989년 동 대학원 전기공학과 졸업(공박). 1981년 1983년 중경공업전문대학 전자과 전임강사. 1983 년 현재 충북대 전기공학부 교수. 1993년, 1998년, 2003년, 2009년 University of Toronto 객원교수. 2005년 2008년 당 학회 부회장. 현재 JPE 편집위원장.

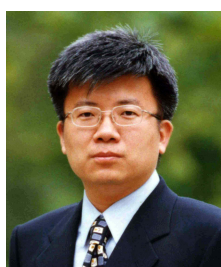

정교범(鄭敎範)

1959년 12월 20일생. 1983년 서울대 공대 전기공학과 졸업. 1985년 동 대학원 전기 공학과 졸업(석사). 1992년 Univ. of Florida(공박). 1992년 1993년 Virginia Tech(Post Doc.). 1993년 1995년 한국전 기연구소 선임연구원. 1995년 현재 홍익대 전자-전기공학 과 교수. 당 학회 국문지 편집위원장. 